\title{
TINDAK TUTUR PADA PESAN SINGKAT (SMS) LAYANAN MASYARAKAT AUTOMATIS OLEH SATGAS PENANGANAN COVID-19
}

\author{
Trian Ramadhan Nuryadin \\ Universitas Padjadjaran \\ trianrn33@gmail.com
}

\begin{abstract}
Abstrak
Speech act atau tindak tutur adalah satuan lingual yang bersifat inti dalam kajian pragmatik. Tindak tutur sendiri memiliki impikatur yang berbeda dan disandarkan pada konteks yang melekat pada wacananya. Penelitian semacam ini memang telah banyak dilakukan namun pada penelitian ini peneliti mengambil sumber data yang menarik yaitu dari pesan singkat automatis yang dikirim oleh satuan tugas penanganan COVID-19. Penelitian ini adalah jenis penelitian kualitatif yang menggunakan metode deskriptif karena penelitian ini hanya terfokus pada jenis-jenis tindak tutur yang terdapat pada pesan singkat layanan masyarakat terkait pencegahan penyebaran virus COVID-19. Pada penelitian ini juga penulis mengunakan teori-teori tindak tutur Searle (1979) dengan pendekatan kajian pragmatik. Ditemukan dari 17 data yang didapat, data berupa pesan singkat dapat bagi kedalam jenis-jenis tindak tutur, yaitu; 5 data pada jenis tindak tutur direktif, 5 data pada jenis tindak tutur asertif, 1 data pada jenis tindak tutur ekspresif, 4 data pada tindak tutur komisif, dan 2 data pada jenis tindak tutur deklarasi.
\end{abstract}

Kata Kunci: tindak tutur, pesan singkat, COVID-19

\begin{abstract}
Speech act is a lingua unit which is the core character in pragmatic studies. The speech act itself has a different impicture and is based on the context inherent in the discourse. This kind of research has indeed been done a lot, but in this study researchers took an interesting source of data, namely from automatic short messages sent by the task force for handling COVID-19. This research is a type of qualitative research that uses a descriptive method because this research only focuses on the types of speech acts found in short messages of public services related to preventing the spread of the COVID-19 virus. In this study the authors also used Searle's (1979) speech act theories with a pragmatic study approach. Found from the 17 data obtained, the data in the form of short messages can be divided into types of speech acts, namely; 5 data on types of directive speech acts, 5 data on types of assertive speech acts, 1 data on types of expressive speech acts, 4 data on types of commissive speech acts, and 2 data on types of declaration speech acts.
\end{abstract}

Keywords: speech acts, short messages, COVID-19

\section{PENDAHULUAN}

Bahasa merupakan satuan terpenting dalam berkomunikasi, bahasa menjadi perantara komunikasi antara penutur dan mitra tuturnya dalam banyak hal, seperti mengungkapkan perasaan, fikiran hingga harapan. Pemakaian bahasa dapat ditemui diberbagai segi kehidupan sehari-hari seperti komunikasi langsung maupun tidak langsung, di perkembangan zaman ini teknologi semakin canggih hingga dapat memungkinkan manusia dapat berkomunikasi secara virtual atau daring, salah 
satunya pesan singkat Short Massage Service disingkat SMS. Bahasa dalam pesan singkat SMS dapat mengungkapkan semua hal itu secara singkat dan tegas.

Indah (2008: 1) dalam artikelnya yang berjudul "Proses Pemerolehan Bahasa: Dari Kemampuan Hingga Kekurangmampuan Berbahasa" menyatakan bahwa "Manusia dirancang untuk berjalan, tetapi tidak diajari agar bisa berjalan. Demikian pula dalam berbahasa, tidak seorang pun bisa diajari bahasa karena manusia ciptakan untuk berbahasa. Dalam artian bahwa pada kenyataannya manusia akan berbahasa tanpa bisa dicegah agar dia tidak memperoleh bahasa" hal itu senada dengan Noam Chomsky, bapak Linguistik dunia yang menyebutkan bahwa apabila kita mempelajari bahasa maka sebenarnya kita sedang mempelajari apa arti dari manusia, yang menjadikan keunikan manusia itu sendiri.

Kehadiran SMS menjadi suatu media berbahasa dua arah maupun satu arah sebagai alat berkomunikasi maupun menjadi wadah informasi dan imbauan, ketika dunia sedang dihebohkan dengan beredarnya wabah COVID-19 semua negara seakan berlomba-lomba mengembalikan keadaan menjadi normal kembali, perlunya adaptasi kebiasaan baru bagi masyarakat membuat satuan tugas penanganan COVID-19 mengunakan media pesan singkat SMS sebagai media informasi yang praktis untuk menghimbau masyarakat mengikuti protokol kesehatan dan adaptasi kebiasaan baru ketika pandemi. Hal tersebut senada dengan apa yang dijelaskan oleh Yule (2006: 82) bahwa tindak tutur yaitu tindakan-tindakan yang ditampilkan lewat tuturan. Oleh karena itu dalam setiap tuturan yang dituturkan akan memiliki maksud tertentu yang dibangun oleh penutur agar mitra tutur tersebut mengerti atas tuturanya. Termasuk latar belakang penuturan tuturan tersebut, selanjutnya dapat disimpulkan bahwa tindak tutur adalah kegiatan berujar dilatarbelakangi dengan maksud tertentu.

Teori tindak tutur telah dikaji dan masuk dalam kajian pragmatik. Speech act atau tindak tutur adalah satuan lingua yang bersifat inti dalam kajian pragmatik. Rustono (1999: 33) menyimpulkan bahwa tindak ujar atau tindak tutur merupakan kegiatan melakukan tindakan mengujarkan tuturan. Dapat diartikan bahwa tindak tutur adalah satuan fungsional dalam komunikasi. Tuturan sendiri memliki tujuan dan latar belakang agar terjalinya suatu komunikasi. Tujuanya adalah untuk menyampaikan informasi, menyarankan, ataupun memerintah. Dalam hal ini seorang penutur harus dapat menyakinkan mitra tutur atas maksud tuturanya.

Menurut Austin (1962) dalam bukunya yang berjudul "How to Do Thing with Words" menyebutkan bahwa tindak tutur di bagi menjadi tiga macam, 1) Tindak Lokusi adalah tindakan mengucapkan sesuatu dengan kata dan makna kalimat yang ditetapkan; 2) Tindak Ilokusi adalah tindakan yang mempunyai makna terkandung dalam tuturan, yaitu berusaha untuk mempengaruhi lawan tutur dengan melakukan sesuatu atas tuturannya; 3) Tindak Perlokusi adalah tindakan untuk mempengaruhi pendengarnya atau tindak tutur yang memiliki daya pengaruh atau efek bagi lawan tuturnya. 
Selanjutnya Searle (1969) menggolongkan tindak tutur ilokusi dalam aktivitas bertutur tsb. ke dalam lima macam bentuk tuturan yang masing-masing memiliki fungsi komunikatifnya sendiri, yaitu:

\section{Asertif (Assertives)}

Adalah bentuk tutur yang mengikat penutur pada kebenaran proposisi yang diungkapkan; menyatakan, menyarankan, mengeluh, mengklaim, dll.

2. Direktif (Directives)

Adalah bentuk tutur yang dimaksudkan penuturnya untuk membuat pengaruh agar sang mitra tutur melakukan tindakan tertentu; memohon, memerintah, merekomendasi, memesan, dll.

\section{Ekspresif (Expressives)}

Adalah bentuk tuturan yang mempunyai fungsi untuk menyatakan atau menunjukkan sikap psikologis penutur terhadap suatu keadaan; berterima kasih, memberi selamat, menyalahkan, memuji, berbela sungkawa, dll.

\section{Komisif (Commissives)}

Adalah bentuk tutur yang berfungsi untuk menyatakan janji atau penawaran; berjanji, bersumpah, menawarkan sesuatu, dll.

5. Deklarasi (Declarations)

Adalah bentuk tutur yang menghubungkan isi tuturan dengan kenyataannya; berpasrah, mengucilkan, memecat, mengangkat, dll.

Dalam hal ini konteks dalam kajian pragmatik sangat perlu digunakan untuk menerjemahkan arti sebuah kalimat yang diujarkan oleh penutur. Oleh karena itu konteks selalu dikaitkan dalam bahasa.

Penelitian semacam ini telah banyak dibahas oleh peneliti lainya namun dalam penelitian ini sumber data yang digunakan masih jarang ditemui, yaitu pesan singkat layanan masyarakat terkait pencegahan penyebaran virus COVID-19 yang dikirim secara masal melalui SMS. Beberapa penelitian sebelumnya yang relevan dengan penelitian ini yaitu; (1) "Tindak Tutur Direktif Dalam Iklan Layanan Masyarakat Di Media Televisi Serta Kemungkinan Efeknya" oleh Nugraha (2018) penelitian tersebut bertujuan untuk menganalisis tuturan direktif dalam iklan layanan masyarakat yang ada di media televisi, memaparkan jenis tuturan direktif, mengidentifikasi jenis tuturan direktif. Penelitian ini dibatasi hanya menalisis dari segi tindak tutur direktif saja.

Selanjutnya (2) pada penelitian “Tindak Tutur Ilokusi Pada Proses Kelahiran Dengan Teknik Hipnosis (Hypnobirthing): Suatu Kajian Pragmatik" oleh Sekarsany (2020) dilatar belakangi oleh tindak tutur tenaga kesehatan pada praktek persalinan dengan menggunakan tekik hipnosis. Pada penelitian ini Sekarsany mengambil data lapangan secara langsung. Namun pada penelitian tersebut hanya berfokus pada komunikasi tenaga medis dengan pasien, berbeda dengan penelitian ini, data yang diambil berupa data pesan singkat layanan masyarakat yang hanya satu arah saja. 
Berpijak dari uraian penjelasan di atas, bahasa yang mengandung tindak tutur dalam pesan singkat layanan masyakarat pencegahan penyebaran COVID-19 dapat dilihat sebagai sebuah fenomena kebahasaan yang dapat dikaji. Sejalan dengan itu Keraf (1997: 1) menjelaskan beberapa fungsi bahasa yaitu; (1) sebagai alat komunikasi, (2) alat untuk mengapresiasikan diri, (3) sebagai alat untuk berkomunikasi dan (4) sebagai alat untuk melakukan kontrol sosial. Fenomena tersebut membuat peneliti berkeinginan untuk mengkaji lebih dalam tentang tindak tutur yang terdapat dalam pesan singkat layanan masyarakat terkait pencegahan penyebaran COVID-19 dengan melihat implikatur dengan pendekatan teori tindak tutur Searle (1979).

\section{METODE PENELITIAN}

Penelitian ini adalah jenis penelitian kualitatif yang menggunakan metode deskriptif karena penelitian ini hanya terfokus pada jenis-jenis tindak tutur yang terdapat pada pesan singkat layanan masyarakat terkait pencegahan penyebaran virus COVID-19. Penelitian kualitatif merupakan penelitian yang bermaksud untuk memahami fenomena tentang apa yang dialami oleh subjek penelitian misalnya perilaku, presepsi, motivasi, tindakan dan dengan cara deskripsi dalam bentuk katakata dan bahasa, pada suatu konsep khusus yang alamiah dan dengan memanfaatkan berbagai metode ilmiah (Moleong, 2000: 6).

Sumber data dalam penelitian ini di ambil dari pesan singkat layanan masyarakat terkait pencegahan penyebaran virus COVID-19. Teknik pengumpulan data menggunakan metode simak, dengan teknik dasar dari metode ini yaitu teknik catat dengan maksud untuk mencatat data yang sudah disimak dari sumber data.

Analisis data dalam penelitian ini menggunakan metode padan. Teknik dasar dalam penelitian ini adalah teknik pilah unsur penentu atau teknik PUP. Analisis data merupakan upaya peneliti menangani langsung masalah yang terkandung dalam data (Sudaryanto, 1993:6). Adapun alatnya adalah daya pilah yang bersifat mental yang dimiliki oleh peneliti. Daya pilah yang dimaksud adalah daya pilah referensial. Melalui daya pilah tersebut dapat diketahui jenis tindak tutur yang diucapkan penutur melalui konteksnya. Kemudian dilakukan pengolahan data dengan mengamati dan menganalisis ujaran-ujaran yang terkait dengan tindak tutur. Kemudian, peneliti mencatat dan mengklasifikasi tuturan-tuturan tersebut berdasarkan ke dalam penjenisan tindak tutur. Setelah itu, data yang berupa tuturan tersebut dianalisis dengan menggunakan pendekatan pragmatik yakni pendekatan yang selalu berkaitan dengan konteks yang mewadahi dan melatar belakangi sebuah tuturan dan implikaturnya.

\section{HASIL DAN PEMBAHASAN}

Setelah peneliti mengambil beberapa data dari sumber terkait penulis menemukan 18 data, selanjutnya guna mendapatkan dan mendeskripsikan hasil dari penelitian, data tersebut diklasifikasi dan dianalisis berdasarkan jenis tindak tutur 
yang ditemukan pada pesan singkat layanan masyarakat terkait pencegahan penyebaran virus COVID-19. Berikut uraian pemaparan, sebagai berikut:

\subsection{Tindak Tutur Asertif}

Tabel 1 Data Tindak Tutur Asertif

\begin{tabular}{|c|c|c|c|}
\hline No & Tindak Tutur Asertif & Jenis & Penanda \\
\hline 1 & $\begin{array}{l}\text { Siapapun dapat membawa dan menyebarkan } \\
\text { virus corona tanpa disadari termasuk antar- } \\
\text { teman sendiri. Ayo, pakai masker yang benar } \\
\text { untuk akhiri wabah. }\end{array}$ & $\begin{array}{l}\text { Menyatakan } \\
\text { dan } \\
\text { menyarankan }\end{array}$ & $\begin{array}{l}\text { "Siapapun" dan } \\
\text { "Ayo" }\end{array}$ \\
\hline 2 & $\begin{array}{l}\text { Berdasarkan penelitian, } 95 \% \text { efek samping } \\
\text { vaksin bersifat ringan, misal demam paling } \\
\text { lama } 48 \text { jam. Itu bukti keamanan vaksin yang } \\
\text { terus dijaga. }\end{array}$ & $\begin{array}{l}\text { Menyatakan } \\
\text { dan mengkalim }\end{array}$ & $\begin{array}{l}\text { "Berdasarkan" } \\
\text { dan "misal" }\end{array}$ \\
\hline 3 & $\begin{array}{l}\text { Tak kenal maka tak kebal! Imunisasi bangun } \\
\text { antibodi tubuh, kurangi risiko tertular } \\
\text { penyakit. Imunisasi selamatkan jiwa dan } \\
\text { kendalikan wabah. }\end{array}$ & $\begin{array}{l}\text { Menyatakan } \\
\text { dan } \\
\text { menyarankan }\end{array}$ & $\begin{array}{l}\text { "bangun" dan } \\
\text { "selamatkan" }\end{array}$ \\
\hline 4 & $\begin{array}{l}\text { Vaksin diproduksi dengan standar } \\
\text { keamanan tinggi, melalui prosedur uji klinik } \\
\text { ketat. Saat digunakan pun perlu izin dan } \\
\text { diawasi oleh Badan POM covid19.go.id }\end{array}$ & $\begin{array}{l}\text { Menyatakan } \\
\text { dan mengkalim }\end{array}$ & $\begin{array}{l}\text { "diproduksi" } \\
\text { dan "diawasi" }\end{array}$ \\
\hline 5 & $\begin{array}{l}\text { Corona hanya butuh waktu singkat menulari } \\
\text { orang. Di saat bertemu orang: jaga jarak, } \\
\text { jangan pernah lepas masker \& sering cuci } \\
\text { tangan pakai sabun. }\end{array}$ & $\begin{array}{l}\text { Menyatakan } \\
\text { dan } \\
\text { menyarankan }\end{array}$ & $\begin{array}{l}\text { "Butuh" dan } \\
\text { "bertemu" }\end{array}$ \\
\hline
\end{tabular}

A. Data 1

Eksplikatur dalam data (1) adalah "Siapapun dapat membawa dan menyebarkan virus corona tanpa disadari termasuk antar-teman sendiri. Ayo, pakai masker yang benar untuk akhiri wabah." Ditandai dengan penanda "sebaiknya", adapun konteks wacana di atas didapat dari pesan singkat layanan masyarakat satuan gabungan pencegahan penyebaran virus COVID-19. Tujuan wacana tersebut untuk menyatakan pernyataan dan himbauan ini berimplikatur untuk menghimbau masyarakat agar lebih sadar dengan masifnya penyebaran virus COVID-19. Tindak tutur asertif menghimbau yaitu suatu tindak tutur yang menyuruh atau menghimbau mitra tutur agar mengikuti himbauan penutur wacana tersebut. Wacana pesan singkat tersebut merupakan tuturan yang bermaksud mengingatkan dengan cara menghimbau masyarakat untuk terus mengunakan masker guna mengakhiri pandemi COVID-19, tingginya penyebaran virus COVID-19 di Indonesia menjadi latar belakang terjadinya tuturan ini.

\section{B. Data 2}

Eksplikatur dalam data (2) adalah “Berdasarkan penelitian, 95\% efek samping vaksin bersifat ringan, misal demam paling lama 48 jam. Itu bukti keamanan vaksin yang terus dijaga." Ditandai dengan penanda "Berdasarkan" dan "misal" adapun konteks wacana di atas didapat dari pesan singkat layanan masyarakat satuan gabungan pencegahan penyebaran virus COVID-19. Tujuan wacana diatas untuk menyatakan dan mengklaim di atas berimplikatur untuk 
memberikan informasi kepada masyarakat terkait vaksin COVID-19. Tindak tutur asertif mengkalim digunakan untuk mengonfirmasi suatu data yang diawali oleh kebenaran proposisi, yang dimaksud dalam tuturan ini adalah suatu hasil riset sebagai contoh nyata dari efek samping dari pemakaian vaksin. Wacana pesan singkat ini merupakan tuturan yang dimaksudkan untuk medukasi masyarakat tentang vaksin dan disisipi dengan hasil riset tentang vaksin untuk mengkalim pernyataan kebenaran proposisi sebelumnya, riuh ditengah masyarakat tentang perdebatan baik buruknya penggunaan vaksin COVID-19 ini yang melatar belakangi wacana ini.

\section{Data 3}

Eksplikatur pada data (3) adalah “Tak kenal maka tak kebal! Imunisasi bangun antibodi tubuh, kurangi risiko tertular penyakit. Imunisasi selamatkan jiwa dan kendalikan wabah." Ditandai dengan penanda "bangun" dan "selamatkan" adapun konteks wacana di atas didapat dari pesan singkat layanan masyarakat satuan gabungan pencegahan penyebaran virus COVID-19. Tujuan wacana diatas untuk menyatakan dan menyarankan pada tuturan ini berimplikatur untuk medukasi masyarakat tentang imunisasi yang dapat menjadi antibodi tubuh dan mengurangi risiko penularan penyakit. Tindak tutur asertif menyarankan digunakan untuk menghimbau dan memberi tahu mitra tutur tentang kebenaran proposisi yang dimaksud. Wacana pesan singkat ini merupakan tuturan yang dimaksudkan untuk memberi tahu masyarakat akan pentingnya imunisasi guna kekebalan tubuh atas segala penyakit, keraguan masyarakat akan imunisasi menjadi latar belakang yang melatar belakangi terjadinya tuturan ini.

D. Data 4

Eksplikatur ada data (4) adalah "Vaksin diproduksi dengan standar keamanan tinggi, melalui prosedur uji klinik ketat. Saat digunakan pun perlu izin dan diawasi oleh Badan POM covid19.go.id" Ditandai dengan penanda "diproduksi" dan "diawasi" adapun konteks wacana di atas didapat dari pesan singkat layanan masyarakat satuan gabungan pencegahan penyebaran virus COVID-19. Tujuan wacana diatas untuk menyatakan dan mengklaim pada tuturan ini berimplikatur untuk meinformasikan tentang vaksin COVID-19 yang sedang diproduksi dengan standar yang tinggi. Tindak tutur mengkaim digunakan guna menegaskan bahwa standar kemanan tinggi dan prosedur uji klinik yang ketat menjadikan kebenaran untuk proposisi yang dimaksud. Wacana pesan singkat ini dimaksudkan untuk medukasi dan meinformasikan masyarakat akan tingginya kualitas vaksin COVID-19 ini, banyaknya pertanyaan masyarakat akan terujinya vaksin COVID-19 ini melatar belakangi terjadinya tuturan ini.

\section{E. Data 5}

Eksplikatur pada data (5) adalah "Corona hanya butuh waktu singkat menulari orang. Di saat bertemu orang: jaga jarak, jangan pernah lepas masker \& sering cuci tangan pakai sabun." Ditandai dengan penanda "Butuh" dan "bertemu" 
adapun konteks wacana di atas didapat dari pesan singkat layanan masyarakat satuan gabungan pencegahan penyebaran virus COVID-19. Tujuan wacana diatas untuk menyarankan dan menyatakan ini berimplikatur untuk meninformasikan tentang cepatnya perkembangan virus corona, dan bagaimana cara penularanya yang begitu mudah terjadi. Tindak tutur menyarankan di sini digunakan untuk menghimbau masyarakat untuk tidak melepas masker dan sesering mungkin mencuci tangan. Wacana pesan singkat ini dimaksudkan untuk masyarakat awam yang belum banyak mengetahui tentang informasi penyebaran virus COVID-19, banyaknya lapisan masyarakat Indonesia yang belum mengetahui pentingnya mengunakan masker dan mencuci tangan menjadi latar belakang dituturkannya wacana ini.

\subsection{Tindak Tutur Direktif}

Tabel 2 Data Tindak Tutur Direktif

\begin{tabular}{|c|c|c|c|}
\hline No & Tindak Tutur Direktif & Jenis & Penanda \\
\hline 1 & $\begin{array}{l}\text { Masa Pandemi, ibu hamil sebaiknya tetap } \\
\text { \#DiRumahAja untuk jaga kesehatan diri dan } \\
\text { janin. Namun tetap boleh keluar guna kontrol } \\
\text { rutin ke yankes. }\end{array}$ & $\begin{array}{l}\text { Memohon dan } \\
\text { memerintah }\end{array}$ & "sebaiknya" \\
\hline 2 & $\begin{array}{l}\text { Jangan beri peluang corona masuk rumah. } \\
\text { Ingatkan anggota keluarga yang keluar rumah: } \\
\text { selalu jaga jarak, pakai masker dan cuci tangan } \\
\text { pakai sabun. Covid19.go.id }\end{array}$ & $\begin{array}{l}\text { Memohon dan } \\
\text { memerintah }\end{array}$ & $\begin{array}{l}\text { "jangan" dan } \\
\text { "selalu" }\end{array}$ \\
\hline 3 & $\begin{array}{l}\text { Gunakan Hak Pilihmu. Ayo ke TPS. Suara kita } \\
\text { menentukan masa depan bangsa! Tetap } \\
\text { \#PakaiMasker \#JagaJarak. Jangan berkerumun } \\
\text { di sekitar TPS. }\end{array}$ & $\begin{array}{l}\text { Memohon dan } \\
\text { memerintah }\end{array}$ & $\begin{array}{l}\text { "gunakan" } \\
\text { dan "tetap" }\end{array}$ \\
\hline 4 & $\begin{array}{l}\text { Jangan biarkan orang rumah keluar tanpa } \\
\text { masker. Awasi karena virus corona mudah } \\
\text { menular di antara anggota keluarga bila ada } \\
\text { yang membawa ke rumah. covid19.go.id }\end{array}$ & $\begin{array}{l}\text { Memohon dan } \\
\text { memerintah }\end{array}$ & $\begin{array}{l}\text { “jangan” } \\
\text { “awasi” }\end{array}$ \\
\hline 5 & $\begin{array}{l}\text { Ventilasi ruangan buruk meningkatkan risiko } \\
\text { penularan COVID-19. Jika harus di luar rumah, } \\
\text { hindari tempat ramai, sempit dan / atau } \\
\text { tertutup. covid19.go.id }\end{array}$ & $\begin{array}{l}\text { Memohon dan } \\
\text { memerintah }\end{array}$ & "hindari" \\
\hline
\end{tabular}

\section{A. Data 1}

Eksplikatur pada data (1) adalah "Masa Pandemi, ibu hamil sebaiknya tetap \#DiRumahAja untuk jaga kesehatan diri dan janin. Namun tetap boleh keluar guna kontrol rutin ke yankes." Ditandai dengan penanda "sebaiknya" adapun konteks wacana di atas didapat dari pesan singkat layanan masyarakat satuan gabungan pencegahan penyebaran virus COVID-19. Tujuan wacana diatas untuk memohon dan memerintah disini berimplikatur untuk memerintah masyarakat khususnya ibu hamil untuk menetap dirumah jika tidak ada kepentingan yang esensial. Tindak tutur memohon disini digunakan untuk memohon ibu hamil untuk tidak berpergian kecuali untuk kontrol rutin ke yankes. Wacana pesan singat ini dilatar belakangi dengan banyaknya pasien positif pada ibu hamil. 
B. Data 2

Eksplikatur pada data (2) adalah “Jangan beri peluang corona masuk rumah. Ingatkan anggota keluarga yang keluar rumah: selalu jaga jarak, pakai masker dan cuci tangan pakai sabun. Covid19.go.id" ditandai dengan penanda "jangan" dan "selalu" adapun konteks wacana di atas didapat dari pesan singkat layanan masyarakat satuan gabungan pencegahan penyebaran virus COVID-19. Tujuan wacana diatas untuk memohon dan memerintah disini berimplikatur untuk memohon masyarakat agar jangan memberi peluang virus masuk kedalam tempat tinggal. Wacana pesan singkat ini dimaksudkan untuk menghimbau pengunaan protokol kesehatan selama masa pandemi COVID-19, banyaknya masyarakat yang belum tahu akan pentingnya protokol kesehatan dimasa pandemi COVID-19 ini melatar belakangi terjadinya tuturan ini.

\section{Data 3}

Eksplikatur pada data (3) adalah "Gunakan Hak Pilihmu. Ayo ke TPS. Suara kita menentukan masa depan bangsa! Tetap \#PakaiMasker \#JagaJarak. Jangan berkerumun di sekitar TPS."Ditandai dengan penanda "gunakan" dan "tetap" adapun konteks wacana di atas didapat dari pesan singkat layanan masyarakat satuan gabungan pencegahan penyebaran virus COVID-19. Tujuan wacana diatas untuk memerintah dan memohon pada wacana ini berimplikatur untuk meinformasikan kepada masyarakat agar mengunakan hak pilih dalam PILKADA. Wacana pesan singkat ini dimaksudkan agar warga tetap mengunakan hak pilihnya untuk meilih calon pemimpin daerahnya dan tetap fokus dalam memutus penyebaran virus COVID-19 dengan cara tidak berkerumun di TPS, banyaknya ketakutan masyarakat akan terpaparnya virus COVID-19 di TPS melatar belakangi terjadinya tuturan ini.

\section{Data 4}

Eksplikatur pada data (4) adalah "Jangan biarkan orang rumah keluar tanpa masker. Awasi karena virus corona mudah menular di antara anggota keluarga bila ada yang membawa ke rumah. covid19.go.id" Ditandai dengan penanda "jangan" dan "awasi" adapun konteks wacana di atas didapat dari pesan singkat layanan masyarakat satuan gabungan pencegahan penyebaran virus COVID-19. Tujuan wacana diatas untuk memohon dan memerintah ini memiliki implikatur untuk mengawasi orang sekitar kita untuk tetap mengunakan masker jika berpergian keluar rumah. Wacana pesan singkat ini terjadi karena banyaknya masyarakat yang belum sadar akan pentingnya mengunakan masker jika keluar rumah dan menghimbau orang terdekat untuk selalu memberi tahu dan mengingatkan agar tetap mengikuti protokol kesehatan yang berlaku di masa pandemi COVID-19.

\section{E. Data 5}

Eksplikatur pada data (5) adalah "Ventilasi ruangan buruk meningkatkan risiko penularan COVID-19. Jika harus di luar rumah, hindari tempat ramai, sempit dan / atau tertutup. covid19.go.id" Ditandai dengan penanda "hindari" adapun 
konteks wacana di atas didapat dari pesan singkat layanan masyarakat satuan gabungan pencegahan penyebaran virus COVID-19. Tujuan wacana diatas untuk memohon dan memerintah pada tuturan ini memiliki implikatur untuk memberi tahu masyarakat akan buruknya sirkulasi udara membuat oenyebaran virus COVID19 semakin masif terjadi. Wacana pesan singkat ini terjadi karena banyaknya masyarakat kelas bawah yang tinggal di daerah padat penduduk yang memiliki sistem sirkulasi udara yang buruk pada hunianya, namun tetap menghimbau agar tetap waspada dan mengikuti protokol kesehatan ketika keluar rumah.

\subsection{Tindak Tutur Ekspresif}

Tabel 3 Data Tindak Tutur Ekspresif

\begin{tabular}{clll}
\hline No & \multicolumn{1}{c}{ Tindak Tutur Ekspresif } & Jenis & Penanda \\
\hline 1 & Selamat Hari Anak Nasional 23 Juli! Meski & Memberi & "selamat" \\
& $\begin{array}{l}\text { pandemi, tetap penuhi hak anak, antara lain } \\
\text { mendapat perlindungan, pendidikan, } \\
\text { layanan kesehatan \& gizi. }\end{array}$ & & \\
\hline
\end{tabular}

A. Data 1

Eksplikatur pada data (1) adalah “Selamat Hari Anak Nasional 23 Juli! Meski pandemi, tetap penuhi hak anak, antara lain mendapat perlindungan, pendidikan, layanan kesehatan \& gizi." Ditandai dengan penanda "selamat" adapun konteks wacana di atas didapat dari pesan singkat layanan masyarakat satuan gabungan pencegahan penyebaran virus COVID-19. Tujuan wacana diatas untuk memberi selamat ini memiliki impilkatur untuk memperingati hari anak nasional meskipun ditengah pandemi COVID-19. Wacana pesan singkat ini dilatar belakangi karena adanya lapisan masyarakat yang kesulitan dalam masalah ekonomi ketika masa pandemi, dan wacan memberi selamat ini tidak hanya untuk memperingati, namun juga mengingaytkan akan hak anak mendapatkan gizi yang baik maupun perindungan di tengah pandemi COVID-19.

\subsection{Tindak Tutur Komisif}

Tabel 4 Data Tindak Tutur Komisif

\begin{tabular}{clll}
\hline No & \multicolumn{1}{c}{ Tindak Tutur Komisif } & \multicolumn{1}{c}{ Jenis } & \multicolumn{1}{c}{ Penanda } \\
\hline 1 & Segera kesehatan pulih, ekonomi bangkit di & Menawarkan & "Ekonomi \\
bangkit" & Indonesia. Syarat: patuhi 3M: memakai & sesuatu & \\
& masker, menjaga jarak, mencuci tangan \\
pakai sabun + vaksinasi. & & \\
2 & $\begin{array}{l}\text { Sejak tempo doeloe imunisasi cegah } \\
\text { penyakit menular. Program imunisasi di }\end{array}$ & Menawarkan & "unduh" \\
& $\begin{array}{l}\text { Indonesia sejak 1956. Unduh edukasi vaksin } \\
\text { di http://s.id/infovaksin.covid19.go.id }\end{array}$ & & \\
3 & $\begin{array}{l}\text { Vaksin melatih tubuh untuk kenal, lawan } \\
\text { dan kebal penyebab penyakit, seperti virus }\end{array}$ & Menawarkan & "Unduh"
\end{tabular}


dan bakteri. Unduh buku \#lnfoVaksin di http://s.id/infovaksin.covid19. co.id

4 Tak semua info di Internet benar. Cari tahu soal COVID-19 / vaksin melalui kanal Menawarkan "cari tahu" terpercaya, akun semisal akun medsos @lawancovid19_ID atau situs resmi. covid19.go.id

sesuatu

(n)

\section{A. Data 1}

Eksplikatur pada data (1) adalah "Segera kesehatan pulih, ekonomi bangkit di Indonesia. Syarat: patuhi 3M: memakai masker, menjaga jarak, mencuci tangan pakai sabun + vaksinasi." Ditandai dengan penanda "Ekonomi bangkit" adapun konteks wacana di atas didapat dari pesan singkat layanan masyarakat satuan gabungan pencegahan penyebaran virus COVID-19. Tujuan wacana diatas untuk menawarkan sesuatu dalam tuturan ini berimplilkatur untuk mengajak bersemangat untuk sehat dan mengembalikan keadaan ekonomi ditengah pandemi COVID-19, dengan memerikan atau menawarkan syarat yaitu mematuhi 3M. wacana pesan singkat ini dilatar belakangi oleh turunya angka perekonomian negara akibat pandemi COVID-19 ini, penutur mengajak agar bersama-sama membangun kembali ekonomi negara dengan cara menaati 3M.

\section{B. Data 2}

Eksplikatur pada data (2) adalah "Sejak tempo doeloe imunisasi cegah penyakit menular. Program imunisasi di Indonesia sejak 1956. Unduh edukasi vaksin di http://s.id/infovaksin.covid19.go.id" Ditandai dengan penanda "unduh" adapun konteks wacana di atas didapat dari pesan singkat layanan masyarakat satuan gabungan pencegahan penyebaran virus COVID-19. Tujuan wacana diatas untuk menawarkan sesuatu dalam tuturan ini berimplikatur untuk mengetahui program imunisasi dengan cara membaca secara lengkap pada tautan yang disimpan diakhir wacana. Wacana pesan singkat ini terjadi karena banyaknya pertanyaan dan keraguan di tengah masyarakat akan imunisasi di tengah pandemi COVID-19, penutur penawarkan mitra tuturnya agar membaca secara lengkap edukasi vaksin yang dapat di unduh di tautan.

\section{Data 3}

Eksplikatur pada data (3) adalah "Vaksin melatih tubuh untuk kenal, lawan dan kebal penyebab penyakit, seperti virus dan bakteri. Unduh buku \#lnfoVaksin di http://s.id/infovaksin.covid19. co.id" Ditandai dengan penanda "Unduh" adapun konteks wacana di atas didapat dari pesan singkat layanan masyarakat satuan gabungan pencegahan penyebaran virus COVID-19. Tujuan wacana diatas untuk menawarkan sesuatu ini memiliki implikatur yang sama dengan pesan singkat sebelumnya, penutur menerangkan pentingnya vaksin guna melatih tubuh untuk melawan virus yang masuk. Wacana pesan singkat ini dilatar belakangi banyaknya pertanyaan dimasyarakat tentang kualitas vaksin COVID-19, penutur mengajak dan 
menawarkan kepada masyarakat untuk membaca edukasi tentang vaksin pada laman yang tersedia.

\section{Data 4}

Eksplikatur pada data (4) adalah "Tak semua info di Internet benar. Cari tahu soal COVID-19 / vaksin melalui kanal terpercaya, akun semisal akun medsos @lawancovid19_ID atau situs resmi. covid19.go.id" Ditandai dengan penanda "cari tahu" adapun konteks wacana di atas didapat dari pesan singkat layanan masyarakat satuan gabungan pencegahan penyebaran virus COVID-19. Tujuan wacana diatas untuk menawarkan sesatu pada tuturan ini berimplikatur untuk masyarakat agar lebih sadar tentang kebenaran berita yang tersebar di dunia maya. Wacana pesan singkat ini dilatar belakngi oleh banyaknya berita palsu tentang imunisasi, vaksin, dan angka kematian akibat COVID-19 yang beredar cepat di masyarakat melalui dunia maya, penutur juga mengajak mitra tuturnya untuk mengakses informasi dari kanal yang terpercaya.

\subsection{Tindak Tutur Deklarasi}

Tabel 4 Data Tindak Tutur Deklarasi

\begin{tabular}{clcc}
\hline No & \multicolumn{1}{c}{ Tindak Tutur Deklarasi } & Jenis & Penanda \\
\hline 1 & Waspada, tetaplah patuh jalankan protokol & mengangkat & "musuh" \\
& kesehatan dimanapun kita berada. COVID- 19 & & \\
& musuh tak kasat mata, mengincar tiap momen \\
& kelengahan kita. covid19.go.id & & \\
2 & $\begin{array}{l}\text { Kalau Anda bawa masker cadangan yang baru, } \\
\text { berikan pada yang tidak bermasker. Sampaikan } \\
\text { bahwa Anda tak mau melihatnya tertular virus } \\
\text { corona. }\end{array}$ & & \\
\end{tabular}

A. Data 1

Eksplikatur pada data (1) adalah "Waspada, tetaplah patuh jalankan protokol kesehatan dimanapun kita berada. COVID- 19 musuh tak kasat mata, mengincar tiap momen kelengahan kita. covid19.go.id" Ditandai dengan penanda "musuh" adapun konteks wacana di atas didapat dari pesan singkat layanan masyarakat satuan gabungan pencegahan penyebaran virus COVID-19. Tujuan wacana deklarasi mengangkat ini berimplikatur untuk menghimbau masyarakat agar waspada akan virus COVID-19. Wacana pesan singkat ini dilatar belakanhgi banyaknya masyarakat yang tidak patuh akan protokol kesehatan yang harus dijalankan di masa pandemi COVID-19. Tindak tutur deklarasi mengangkat disini dimaksudkan untuk mengangkat virus COVID-19 sebagai bentuk yang nyata pada proposisi sebelumnya.

\section{B. Data 2}

Eksplikatur pada data (2) adalah "Kalau Anda bawa masker cadangan yang baru, berikan pada yang tidak bermasker. Sampaikan bahwa Anda tak mau melihatnya tertular virus corona." Ditandai dengan penanda "tak mau" adapun konteks wacana di atas didapat dari pesan singkat layanan masyarakat satuan 
gabungan pencegahan penyebaran virus COVID-19. Tujuan wacana deklarasi mengucilkan pada tuturan ini berimplikatur untuk memberikan masker lebih kepada orang yang tidak bermasker. Wacana pesan singkat ini dituturkan karena banyaknya masyarakat yang tidak mengunakan masker diluar runagan, wacana deklarasi mengucilkan yang dimaksud disini adalah dengan mengucilkan masyarakat yang tidak mengunakan masker dan berkata bahwa saya tidak mau melihatnya tertular virus COVID-19, tuturan ini dituturkan guna menghubungkan isi tuturan dengan kenyataan.

Pada data tindak tutur asertif ditemukan bahwa tindak tutur tersebut bertujuan untuk menyatakan, menyarankan, dan mengklaim. Selanjutnya pada data tindak tutur direktif ditemukan bahwa tindak tutur direktif bertujuan untuk memohon, dan memerintah. Sedangkan pada data tindak tutur ekspresif ditujukan untuk memberi selamat. Pada tindak tutur komisif ditujukan untuk menawarkan sesuatu. Dan pada data tindak tuturdeklarasi ditujukan untuk mengangkat dan mengucilkan.

\section{PENUTUP}

Hasil penelitian dan pembahasan tentang aspek kebahasaan serta tindak tutur dianggap menarik dan unik karena peneliti pengambil data dari pesan singkat SMS layanan masyarakat terkait pencegahan penyebaran virus COVID-19 yang didistribusikan oleh satuan tugas penaganan virus COVID-19. Berdasarkan hasil penelitian, dapat ditemui pada data-data yang dikumpulkan memiliki jenis-jenis tindak tutur yang beragam, yaitu; 5 data pada jenis tindak tutur direktif, 5 data pada jenis tindak tutur asertif, 1 data pada jenis tindak tutur ekspresif, 4 data pada tindak tutur komisif, dan 2 data pada jenis tindak tutur deklarasi. Maksud tuturan dalam setiap jenis menandakan sebuah impilkatur yang terkandung dalam wacana tersebut. Hampir semua implikatur tersebut bertujuan untuk pencegahan penyebaran virus COVID-19 ditengah pandemi, dan penerapan protokol kesehatan yang ketat.

\section{DAFTAR PUSTAKA}

Austin, J. L. (1962). How do to Things with Words. Oxford: The Clarendon Press.

Indah, R.N. (2008). Proses berbahasa dapat dilakukan dengan dua tahap yaitu pertama, proses penyampaian pikiran atau perasaan seseorang. Lingua Jurnal Ilmu Bahasa dan Sastra, 3(1), 1-17. http:/ / dx.doi.org/10.18860/ling.v3i1.570

Keraf, Gorys. (1997). Komposisi: Sebuah Pengantar Kemahiran Bahasa. Ende-Flores: Nusa Indah.

Moleong, L. J. (2000). Metodologi Penelitian Kualitatif. Bandung: Remaja Rosda Karya Nugraha, D.S. (2018). Tindak Tutur Direktif Dalam Iklan Layanan Masyarakat Di Media Televisi Serta Kemungkinan Efeknya. Jurnal Sastra Indonesia, 7(1), 1020. https://journal.unnes.ac.id/sju/index.php/jsi/article/view/29812/13168 
Rustono. (1999). Pokok-Pokok Pragmatik. Semarang: CV IKIP Semarang Press.

Searle, J.R. (1969). Speech Act: An Essay in the Philosophy of Language. Cambridge: Cambridge University Press.

Searle, J.R. (1979). Expression and Meaning Studies in the Theory of Speech Act. Cambridge: Cambridge University Press

Sudaryanto. (1993). Metode dan Teknik Analisis Bahasa. Yogyakarta: Duta Wacana University Press 